\title{
Past and Future Trajectories of Human Excreta Management Systems: Paris in the Nineteenth to Twenty-First Centuries

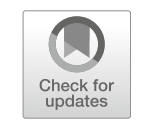

\author{
Fabien Esculier and Sabine Barles
}

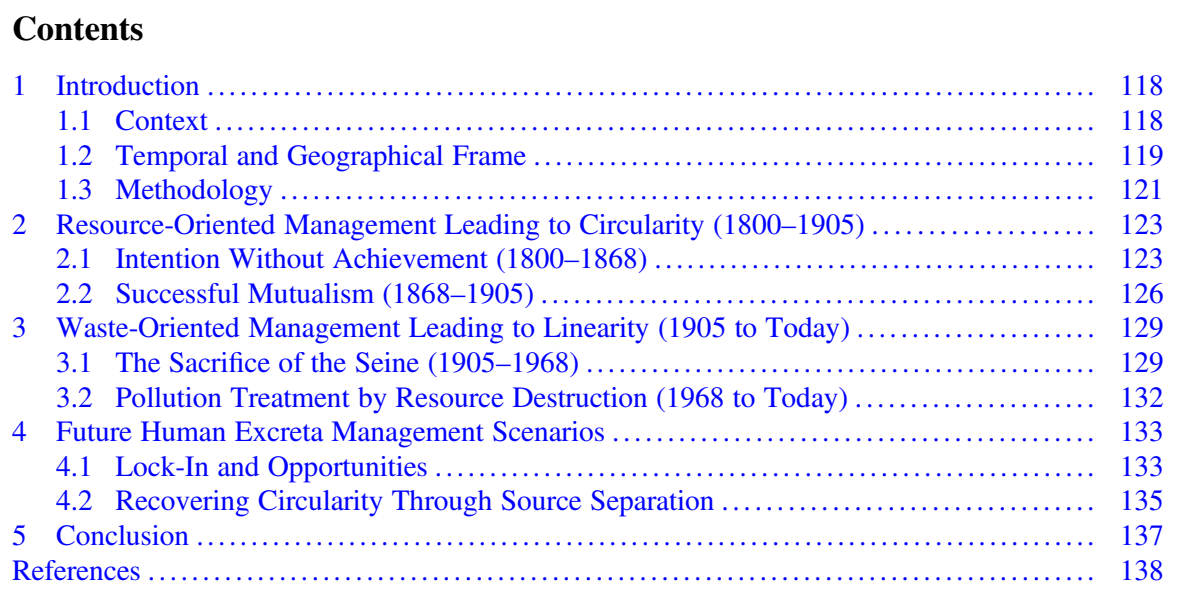

The copyright year of the original version of this chapter was corrected from 2019 to 2020. A correction to this chapter can be found at https://doi.org/10.1007/698_2020_667

\section{F. Esculier $(\bowtie)$}

Laboratoire Eau Environnement et Systèmes Urbains (LEESU), École des Ponts ParisTech, Université Paris-Est Créteil, AgroParisTech, Champs-sur-Marne, France

Milieux Environnementaux, Transferts et Interactions dans les hydrosystèmes et les Sols (METIS), Sorbonne Université, Centre National de la Recherche Scientifique, École Pratique des Hautes Études, Paris, France

e-mail: fabien.esculier@enpc.fr

S. Barles

UMR Géographie-Cités, Université Paris 1 Panthéon-Sorbonne, Université de Paris, École des Hautes Études en Sciences Sociales, Centre National de la Recherche Scientifique, Paris, France 


\begin{abstract}
This chapter addresses the fate of nutrients in agro-food systems after their ingestion by humans. Depending on how human urine and faeces are managed, they can become a source of pollution to the environment, or they can be used as a resource, notably as fertilisers, thus contributing to closing the loop of nutrients. Taking the city of Paris as a case study from the nineteenth to the twenty-first century, we analyse the fate of human excreta through the evaluation of corresponding nitrogen and phosphorus mass flows. We put forward two major phases concerning the management of human excreta:
\end{abstract}

1. The circularisation phase (1800s to 1900s): human excreta management is characterised by increasing circularity which peaks in the 1900 s with around $50 \%$ of human excreta nutrients being recycled.

2. The linearisation phase (1900s-today): human excreta management is characterised by increasing linearity, i.e. a decrease in recycling rates of nutrients. Generalisation and improvement of wastewater treatment have led to decreasing pollution but also confirm the linearisation process (e.g. 5\% recycling of human excreta nitrogen).

This increase in linearity came together with increased dependency of agrosystems on fossil resources. Ongoing climate change is also putting the current system under pressure since the dilution capacity of the Seine River is decreasing, while the population of Paris is increasing. We therefore analyse three scenarios of future human excreta management (incineration, end-of-pipe recycling and source separation) and show that source separation of human excreta may offer the perspective of a sustainable human excreta management system.

Keywords Biogeochemical cycles, Circularity, Human excreta, Nitrogen, Phosphorus, Pollution, Socioecological trajectories, Source separation, Urban metabolism, Urine, Wastewater

\title{
1 Introduction
}

\subsection{Context}

"Flush and forget" toilets are so deeply rooted in the Western way of life that little attention is paid to the fate of our daily excreta. However, raising awareness of the disastrous ecological state to which the development model of Western countries has led, be it eutrophication, climate change or biodiversity loss - to quote only three major transgressions of planetary boundaries [1] - prompts us to question all aspects of the Western way of life. Conventional human excreta management is therefore currently being reconsidered by numerous research projects and innovative implementations, especially in Northern Europe [2] and also more recently in France [3], notably in the OCAPI programme (www.leesu.fr/ocapi) and the PIREN-Seine. On the other hand, past human excreta management has been carefully analysed for Paris in previous studies conducted within the PIREN-Seine programme. It has been 
shown that waste and wastewater are recent "inventions" of the twentieth century [4] and that this current linear economy comes after a period of mutualism where urban waste was considered valuable matter for industry and agriculture.

In this chapter, we aim at giving a long-term perspective of human excreta management by bridging historical studies and the current "reinvention" of alternative management methods. This case study is based on the city of Paris, particularly interesting in the sense that its human excreta management has been well documented since the beginning of the nineteenth century. In addition, its main river, the Seine River, has an increasingly low flow rate in relation to the population of Paris, making water and human excreta management critical issues for this city. We analysed the socioecological trajectory of this territory [5], based on substance flow analysis. As recommended in previous studies [6,7], we focus on nitrogen $(\mathrm{N})$ and phosphorus (P) mass flows to characterise the human excreta management of this area, and we mainly analyse two aspects of this management: circularity vs linearity and pollution. Circularity is defined by the proportion of human excreta, as reflected in $\mathrm{N}$ and $\mathrm{P}$ mass flows, that goes back to agricultural land. Linearity is the opposite of circularity: it is defined as the proportion of human excreta that does not return to agricultural land. Such fractions of human excreta are defined herein as pollution if it is released in a reactive form into the environment.

Our bibliographical review shows that such long-term analyses of human excreta management at the urban level are scarce. Only one study has been identified, on the city of Linköping in Sweden. It shows an abrupt decline of circularity since the beginning of the twentieth century, leading to nearly total linearity in the 1960s [8]. Previous studies by Barles provide a solid basis regarding the management of human excreta in Paris. Numerous historical data and figures concerning human excreta management have already been compiled. For example, Paris $\mathrm{N}$ mass flows were specifically analysed for the years 1817, 1852, 1869, 1888, 1913 and 1931 $[6,9]$. More recently, supplementary data have been gathered to give an overview of $\mathrm{N}$ and $\mathrm{P}$ mass flows related to human excreta management for the 1850-2010 period in the Paris conurbation [7]. In this chapter, we aim at consolidating, updating and extending the scope of these previous studies with a focus on long-term analysis of circularity and pollution.

\subsection{Temporal and Geographical Frame}

Our temporal frame for past management of human excreta is the period 1800-2019. This makes it possible to understand the changing trajectory of $\mathrm{N}$ and $\mathrm{P}$ mass flows, from the search for circularity (nineteenth century) to the advent of linearity. Concerning the prospective approach, the temporal frame is 2020-2100. Given the characteristic rate at which management of human excreta has changed in the past centuries, this temporal frame enables one to project in new socioecological regimes concerning the management of human excreta. 

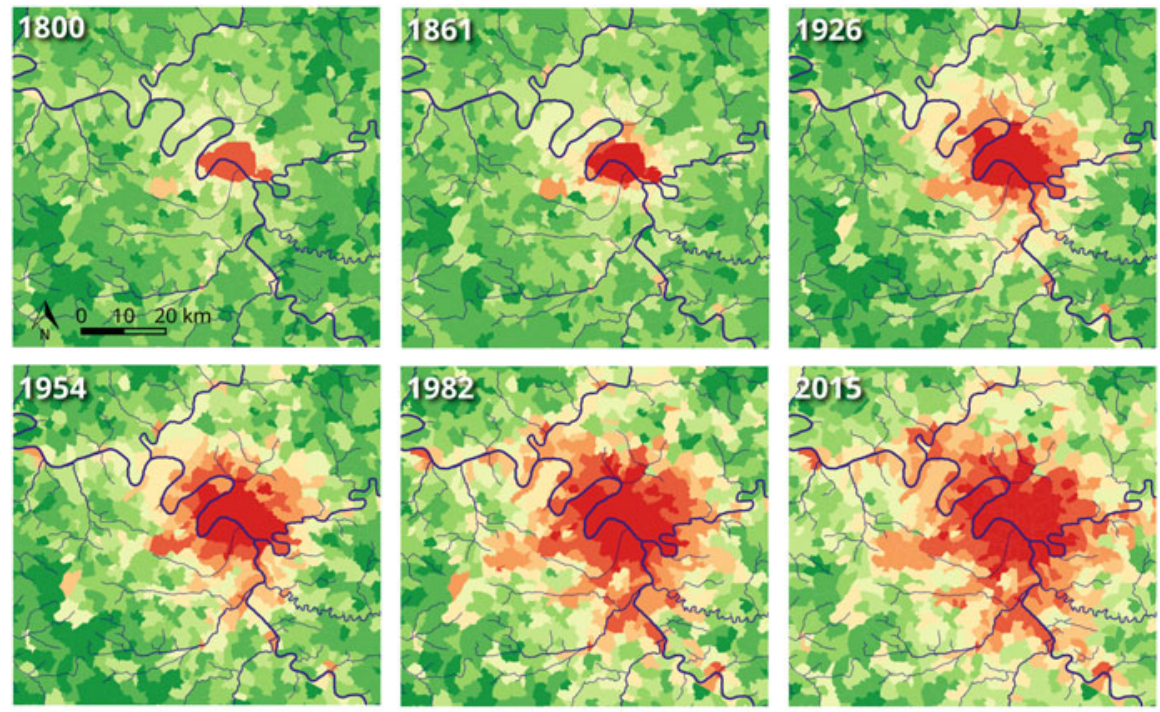

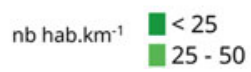
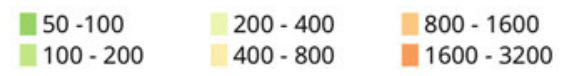

$3200-6400$

Fig. 1 Population density of the municipalities forming the Paris conurbation $(1800,1861,1926$, 1954, 1982 and 2015 general population censuses. Municipal perimeters for the six dates are based on the municipal perimeters of the year 2000. Credit: Sylvain Théry \& Michel Meybeck)

Our geographical frame is the Paris conurbation. We follow the current INSEE ${ }^{1}$ definition of an urban unit: its main characteristic is that the distance between two buildings does not exceed $200 \mathrm{~m}$. During the last two centuries, the perimeter of the Paris conurbation has thus greatly varied (Fig. 1).

The Paris conurbation was included in the administrative limits of Paris at the beginning of the nineteenth century, with a population of approximately 575,000 people in the 1800 s. $^{2}$ In 1860 , the Paris administrative limits were extended to the nearby villages. The population of the city was multiplied by three and reached approximately $1,750,000$ in the 1860 s. In the 1920 s, the conurbation had extended to the surrounding cities of the Seine department, and one-third of the department's population was located outside the city of Paris: the population was multiplied by 2.5 and totalled approximately 4,550,000 inhabitants. In the 1950 s, the population had grown to approximately 5,600,000, one-half inside Paris, one-half in the 123 surrounding cities that formed three new administrative units in 1968 (Hauts-de-Seine, Val-de-Marne and Seine-Saint-Denis). In 2015, the INSEE considered that the

\footnotetext{
${ }^{1}$ Institut National de la Statistique et des Études Économiques: the French National Institute of Statistics and Economic Studies (www.insee.fr).

${ }^{2}$ Population data were taken from general censuses of the population, either directly or through the compilation made by Claude Motte of the Laboratoire de Démographie et d'Histoire Sociale (EHESS).
} 
Paris conurbation comprised 432 municipalities. The city of Paris accounts for approximately one-fifth of this conurbation of approximately 10,700,000 inhabitants.

\subsection{Methodology}

For each decade between 1800 and 2010, we sought to estimate the degree of circularity of human excreta management, i.e. the proportion of $\mathrm{N}$ and $\mathrm{P}$ in human excreta that was returned to agricultural land. For this purpose, we estimated four main parameters:

1. N-DEC is the recycling rate, calculated in terms of $\mathrm{N}$, of human excreta collected through a decentralised device, usually a cesspool, and returned to agricultural land.

2. P-DEC is the same as N-DEC calculated in terms of $P$.

3. N-CENT is the recycling rate, calculated in terms of $\mathrm{N}$, of human excreta collected through a centralised device, i.e. a sewer.

4. P-CENT is the same as N-CENT calculated in terms of P.

These recycling rates were multiplied by the proportion of people connected to a sewer (parameter SEWER) or to a decentralised device (deduced from the parameter SEWER) to obtain the global proportion of $\mathrm{N}$ and $\mathrm{P}$ recycled in the Paris conurbation. Except for denitrification in wastewater treatment plants (WWTPs) and incineration of sludge, all $\mathrm{N}$ and $\mathrm{P}$ that is not recycled in agriculture is considered to be transferred in a reactive form to soil, underground, air or surface water and is thus considered as a pollution.

The data are selected to represent at best each decade: they correspond to the average of the decade when all annual data are available, otherwise the value at the middle of the decade. The parameter SEWER was calculated for the city of Paris on the basis of municipal statistical data [10]. Between the 1870s and the 1910s, the number of Parisians connected to the sewer via a filtering device called a tinette filtrante was estimated [11], considered as a combined centralised and decentralised system.

Outside the city of Paris, the parameter SEWER was linearly increased from $0 \%$ in the 1890 s to $33 \%$ in the 1940s [12] and extrapolated, by taking into account the historical evolution of sewage management [13], to a total connection rate of $98 \%$ estimated in the 2010s [14]. Until the 1940s, it was considered that the connected population of the suburbs was equally distributed between connection to the main sewer network of the Paris conurbation and to an independent suburban sewer network [15].

Data from [7, 10, 13, 15, 16] enabled us to estimate the proportion of four different fates of $\mathrm{N}$ and $\mathrm{P}$ when collected in a sewer: 
- Direct discharge in a river. In this case it was considered that N/P-CENT $=0 \%$ and that all $\mathrm{N}$ and $\mathrm{P}$ resulted in surface water pollution.

- Irrigation fields. In this case it was considered that N/P-CENT $=100 \%$ since all N and $\mathrm{P}$ was spread on fields. Not all $\mathrm{N}$ and $\mathrm{P}$ was actually taken up by crops, but the agronomic efficiency of plant uptake is not taken into account in the calculation of circularity.

- WWTPs with sludge spreading on fields. N/P-CENT is calculated by the proportion of $\mathrm{N}$ and $\mathrm{P}$ contained in sludge. The remaining $\mathrm{P}$ is released to a river as pollution. The remaining $\mathrm{N}$ is either released to a river as pollution or denitrified to the atmosphere in the non-reactive form $\mathrm{N}_{2}$. Despite their importance in terms of the greenhouse gas effect and their high level of emission in Paris WWTPs $[17,18], \mathrm{N}_{2} \mathrm{O}$ emissions were not specifically estimated in this study since the different forms of reactive $\mathrm{N}$ are not distinguished.

- WWTPs with sludge incineration. In this case, N/P-CENT $=0 \%$. Depending on the treatment efficiency, a proportion of $\mathrm{N}$ and $\mathrm{P}$ is released to a river as pollution; the rest of $\mathrm{N}$ is considered to go to the atmosphere in the non-reactive form $\mathrm{N}_{2}$ and $\mathrm{P}$ not released to the river is contained in ashes and usually used as construction material with a loss of the fertilisation potential of $\mathrm{P}$.

For households not connected to a sewer, we based our calculations on the fact that $90 \%$ of $\mathrm{N}$ and $65 \%$ of $\mathrm{P}$ is excreted via urine and the remaining via faeces [7]. N-DEC and P-DEC were calculated as follows:

- The $\mathrm{N}$ excretion of people was taken from $\mathrm{N}$ diet data [19] to which a $20 \%$ decrease was applied to take into account non-ingested food. The multiplication by the total population gave the total amount of $\mathrm{N}$ contained in excretions. $\mathrm{N}$-DEC was calculated on the basis of total quantity and $\mathrm{N}$ content of collected night soil and final products obtained from cesspool management for the 1780s [20] and the years 1817, 1852, 1869, 1911 and 1926 [6, 9, 21, 22]. Data were linearly extrapolated for the missing decades. N-DEC was estimated at $0 \%$ for the period since the 1980s.

- The P content of products obtained from cesspool management was not available in previous studies. The $\mathrm{P}$ recycling rate is expected to be higher than the $\mathrm{N}$ recycling rate since $\mathrm{N}$ does not precipitate and is usually lost in the form of $\mathrm{NH}_{3}$ emissions in cesspool treatment processes, whereas $\mathrm{P}$ remains in the solid and liquid phases [23]. Therefore, the best possible estimate for P-DEC was chosen as the mean value between $\mathrm{N}-\mathrm{DEC}$ and the recycling rate of night soil calculated in volumes.

The combination of the five main parameters, N/P-DEC, N/P-CENT and SEWER, allowed us to estimate the circularity of human excreta management as the total amount of $\mathrm{N}$ and $\mathrm{P}$ returned to agricultural land via night soil processing, field irrigation or sewage sludge spread onto agricultural lands and the total amount of $\mathrm{N}$ and $\mathrm{P}$ pollution to soil, underground and surface water or air. Uncertainty on most data is difficult to quantify. It is considered high for data concerning decentralised management and concerning wastewater management in 
the suburbs of Paris until the 1960s. Concerning the prospective for 2020-2100, the methodology is described in Sect. 4.

\section{Resource-Oriented Management Leading to Circularity (1800-1905)}

\subsection{Intention Without Achievement (1800-1868)}

At the beginning of the nineteenth century, our figures show extremely low rates of circularity in human excreta management: $4 \%$ for $\mathrm{N}$ and $8 \%$ for $\mathrm{P}$ in the $1800 \mathrm{~s}$. The rest of $\mathrm{N}$ and $\mathrm{P}$ is mainly lost at three different stages: (1) just after excretion if excreta are not stored for collection, (2) during storage and (3) in the treatment process.

Some human excreta are abandoned in public and private spaces, even though this practice had been forbidden for centuries - unsuccessfully - and construction of cesspools for each house was mandatory before the sixteenth century [23]. When human excreta are stored in cesspools, only very little of it is eventually collected since leakages lead to transfer to soil and underground water. Cesspool watertightness is for the first time enforced by a decree in 1809 [23]. The proportion of leaking night soil has probably decreased since then, but in 1858, tremendous concentrations, between 29 and $300 \mathrm{mgN} / \mathrm{L}$, were still reported in underground water [24].

Human excreta treatment processes are the third major cause of inefficient recycling. In the eighteenth century, the Paris authorities required that night soil be stored for 3 years before being applied to agricultural land, in order to guarantee salubrity. There is evidence, however, of many farmers being sued because they spread night soil directly on their land [23]. ${ }^{3}$ In 1781, night soil had to be transported to a single facility called the voirie de Montfaucon (Fig. 2). The drying process implemented in 1787 by Jacques Bridet created a greatly appreciated fertiliser called poudrette where nutrients are highly concentrated. But the overall efficiency of uptake of nutrients from the night soil content to the final poudrette product was low: before 1844, most liquids were evaporated, infiltrated in the soil or discharged to surface water, together with their $\mathrm{N}$ and $\mathrm{P}$ content, with specific volatilisation of $\mathrm{N}$ in the form of ammonia. Therefore, $90 \%$ of $\mathrm{N}$ is estimated to be lost in the process [23].

Although regulations tended to favour circularity, the actual materialisation of human excreta management in Paris led to major pollution of soil, underground and surface water and air and a very low recycling rate. Between the 1800s and the 1860 s, however, there were major changes and numerous innovations in human

\footnotetext{
${ }^{3}$ This practice seems common in some places in the countryside but also in urban areas such as Grenoble and Lille [25]. In these areas, the circularity of the process of night soil treatment is probably very high through direct application of liquid night soil and all its $\mathrm{N}$ and $\mathrm{P}$ content.
} 


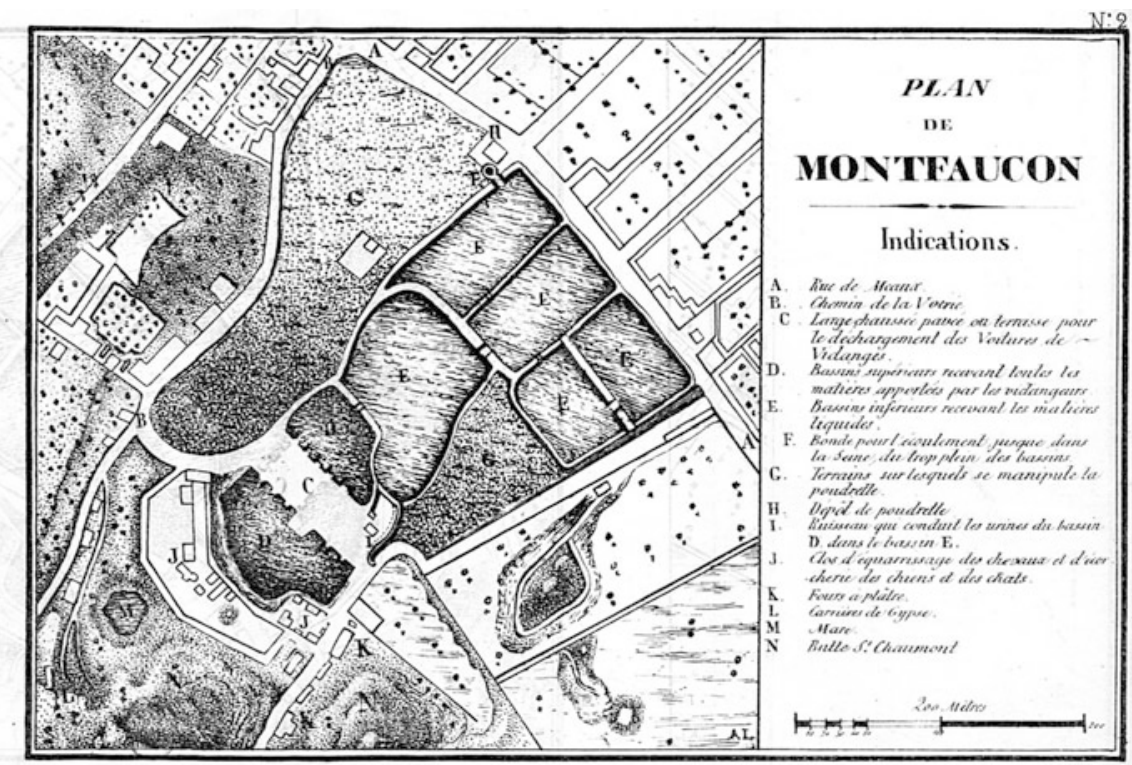

Fig. 2 Map of the voirie de Montfaucon in the beginning of the nineteenth century (Source: Perrot, M. Impressions de voyage - Montfaucon. Paris, chez l'éditeur - 1840. Credit: Gallica)

excreta management, in a context of the industrial revolution and a threefold increase in the urban population. Cesspool watertightness increased the efficiency of collection, but, at the same time, development of water distribution led to higher and more diluted volumes of night soil to collect. Per capita night soil collection was multiplied by five between the 1800s and the 1860s, and total collected night soil volumes were multiplied by 15 . New storage techniques appeared, such as the fosse mobile where night soil was not emptied from a cesspool but stored in a barrel, which was collected together with its content (Fig. 3).

Improvements also appeared at the treatment facility. Numerous inventors, scholars or companies worked on processes that could extract or concentrate the valuable nutrients of human excreta. In 1820, for instance, Joseph Donat received a medal from the Royal and Central Society of Agriculture (known today as the Académie d'Agriculture de France) for his proposal of mixing the liquid part of night soil with an absorbent material to obtain a concentrated fertiliser [26]. Some of these technical improvements were implemented in Paris night soil treatment facilities. In 1852, most night soil treatment had been transferred to Bondy $(10 \mathrm{~km}$ upstream of Paris along the Ourcq canal) where, alongside $10,000 \mathrm{~m}^{3}$ of the traditional poudrette, three other products were obtained by the extraction of $\mathrm{N}$ from the liquid phase: $8 \mathrm{t}$ of ammonium muriate $\left(\mathrm{NH}_{4} \mathrm{Cl}\right), 40 \mathrm{t}$ of volatile alkali $\left(\mathrm{NH}_{4} \mathrm{OH}\right)$ and $835 \mathrm{t}$ of ammonium sulphate $\left(\left(\mathrm{NH}_{4}\right)_{2} \mathrm{SO}_{4}\right)$, which was mostly shipped to England (these figures are for 1852) [27]. 


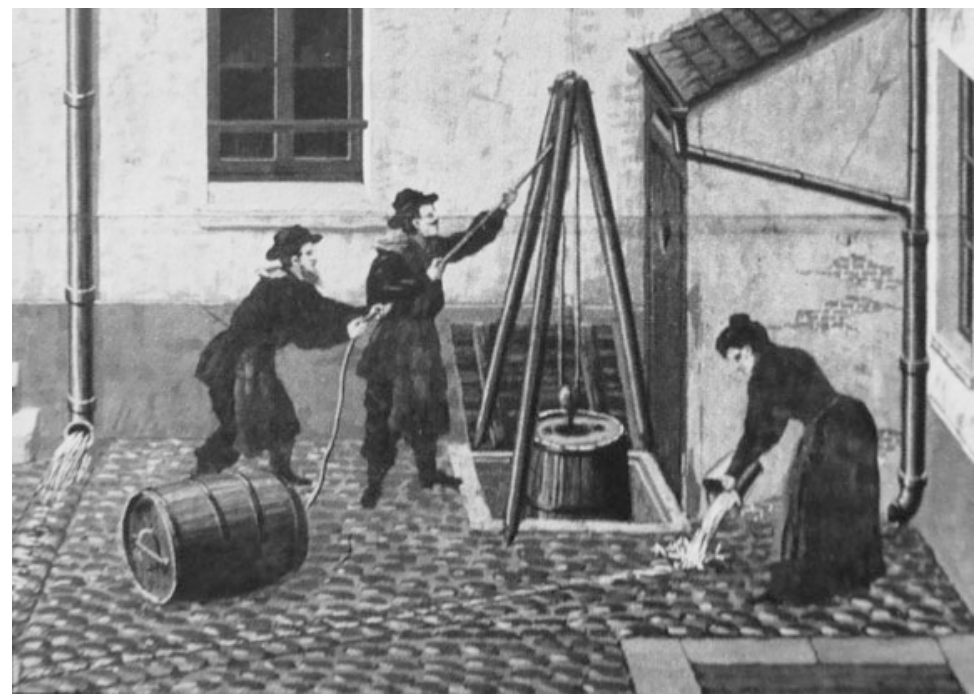

Fig. 3 Collection of night soil in a fosse mobile in 1820 (Detail. Musée d'hygiène de la ville de Paris. Credit: Jacques Boyer/Roger-Viollet)

The combination of these diverse improvements did not lead to radical change in the global circularity of human excreta management. Although between the $1800 \mathrm{~s}$ and the $1850 \mathrm{~s} \mathrm{~N}$ recycling had been multiplied by two, the total $\mathrm{N}$ circularity of Parisians' excreta still did not exceed $10 \%$.

A major change appeared with the extension of sewers. The total length of Paris's sewers timidly rose from $20 \mathrm{~km}$ at the end of the eighteenth century to $40 \mathrm{~km}$ in 1831 and $168 \mathrm{~km}$ in 1858. Their main initial purpose was the collection of rainwater and cleaning water from street fountains. In the first half of the nineteenth century, houses were not connected to the sewers: few houses had a domestic water supply, and dumping human excreta in sewers was considered both unhygienic and a waste of a valuable resource, so it was forbidden. But this changed radically in the middle of the century. As the domestic water supply increased, direct dumping of domestic water on streets became less and less acceptable. In 1852, disposal of domestic water (what is now called grey water) in the sewer became compulsory and general servicing of Paris with the sewer was undertaken. In the 1860s, the total length of the sewers was close to $600 \mathrm{~km}$ [28].

The combination of a steep increase in night soil volumes, extended sewers and the declining quality of the Seine River because of sewage water discharge led engineers to consider another technique to manage human excreta. Flush toilets could be favourably combined with transport of human excreta in the sewers and spreading of the resulting fertiliser-rich water in sewage farms, a technique already implemented abroad [29]. In 1868, engineers Adolphe Mille and Alfred DurandClaye received the authorisation to test sewage spreading on fields in Gennevilliers. Although dry management of human excreta was conducted for the purposes of 
circularity, its practical results led to low circularity, which started to be challenged by wet management of human excreta.

\subsection{Successful Mutualism (1868-1905)}

According to its supporters, the first experiments of sewage spreading on agricultural land were successful. The community of sewage spreading enthusiasts grew larger but still had many opponents: doctors who feared that diseases would be widely spread, fertiliser-makers subjected to competition, owners of buildings who feared the costs of connection to the sewer, the municipalities who were to receive sewage on their lands and of course cesspool emptiers who could see their activity disappear [11]. At the international hygiene congress of 1882 in Geneva, French doctors and hygienists were among the only people to express fears about mixing human excreta with sewage water. London had already launched combined sewers in 1858, and Berlin had made it mandatory in 1874 [12].

The challenge of managing night soil by dry means was also becoming increasingly acute. Between 1868 and 1885, the population had increased by $30 \%$ and collected night soil volumes by $50 \%$. Night soil was becoming more and more diluted and less and less convenient to convert to fertiliser. Whereas London had implemented flush toilets and combined sewers without spreading sewage on agricultural land, circularity was considered a sine qua non condition for adopting flush toilets connected to a sewer in Paris because the Seine had to be protected and the human excreta recycled.

An intermediary solution adopted in Paris is worth mentioning: the tinette filtrante (Fig. 4). It consisted of a filtering device installed on a downpipe. It provided the convenience of having a flush toilet at home with the possibility of recycling organic matter. The tinettes filtrantes had two major flaws: they were subject to clogging, leading to overflows; they retained mostly solid matter, such as faeces or paper, but probably let most of the $\mathrm{N}$, contained in the urine, flow to the sewer and then to the river. Nevertheless, in the 1880s, tinettes filtrantes peaked at $18 \%$ of buildings being equipped with in Paris.

Collection of human excreta in sewers together with spreading on fields finally came into practice in the 1880s. The connection of houses to sewers was made optional in 1885 and mandatory after the 1894 tout-à-l'égout law. This law stated that all houses that were served by the sewer network were compelled to discharge their excreta in the sewer within 3 years (Fig. 5). The connection rate rose but not as fast as expected due to various oppositions. There was less than $1 \%$ connection in the 1880s, $10 \%$ connection in 1895 and already 55\% connection in 1905 (Fig. 8).

In a few decades, Paris had shifted from dry collection of human excreta to a prevailing collection in sewers. Sewage farms increased in size, covering 5,000 ha in the 1900s (Fig. 6). During this decade, the mean proportion of sewage water spread on land was $74 \%$. Sewers were collecting more water due to the rise in the population and water consumption but also more organic matter and nutrients due 


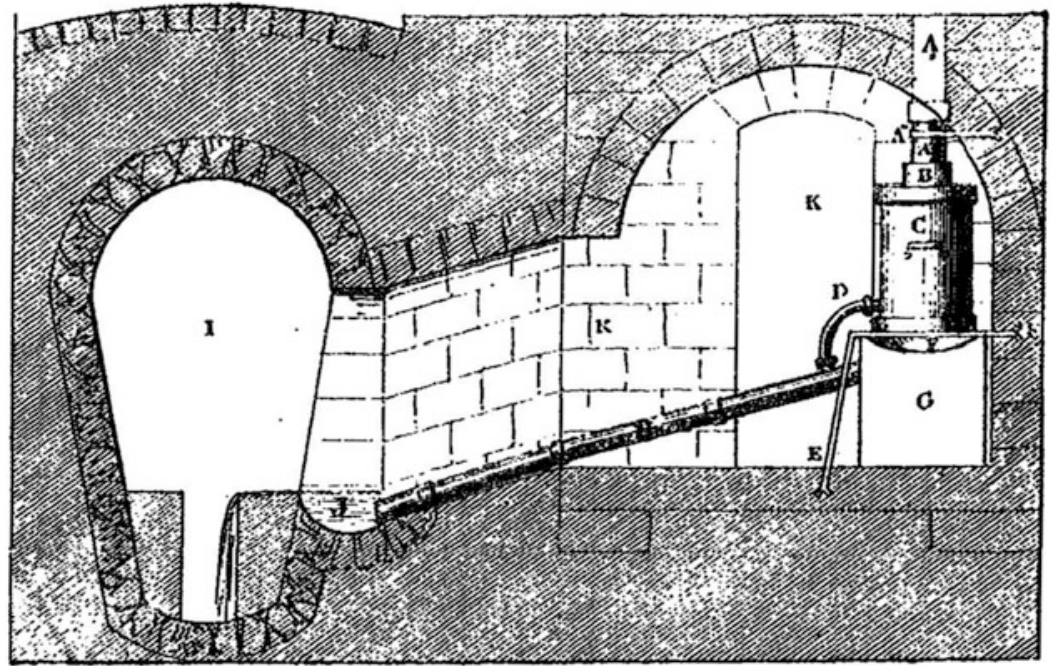

Fig. 4 Scheme of a tinette filtrante. Solids are kept in the barrel (C) while liquids flow to the sewer (I) [30] (Credit: Gallica)

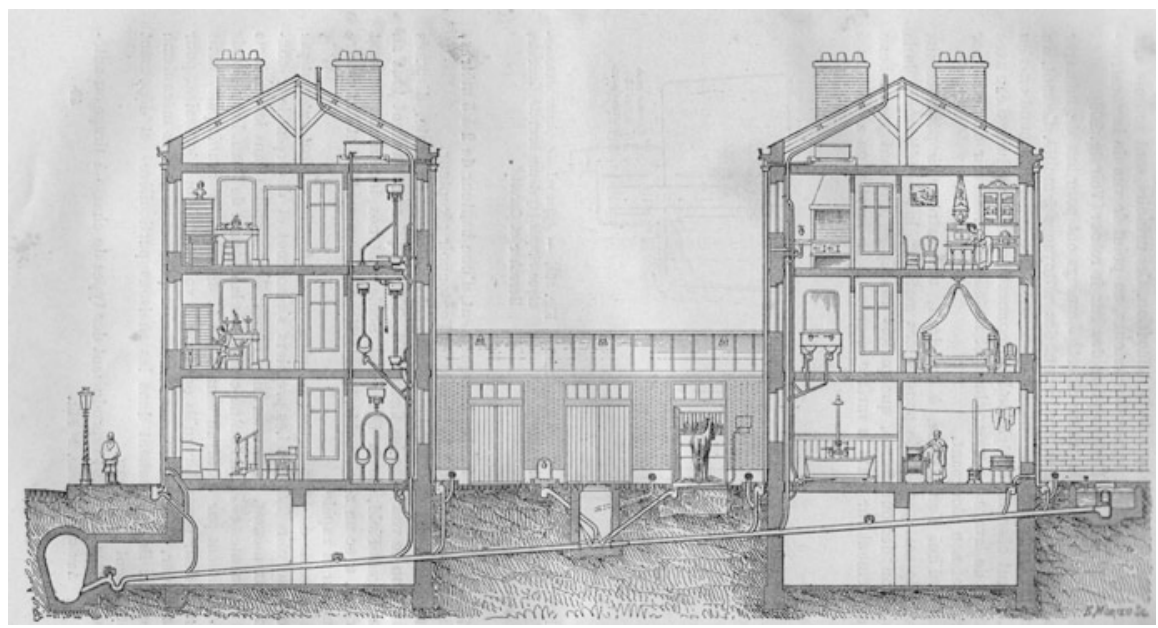

Fig. 5 House drainage, 1880s [31]

to the connection of toilets to the sewer. Much less of Paris sewage water was directly discharged into the river.

In terms of circularity, the situation radically changed within a few decades. The recycling efficiency of dry collection and treatment (N-DEC) had been steadily but slowly rising since the beginning of the nineteenth century. Thanks to improvements 


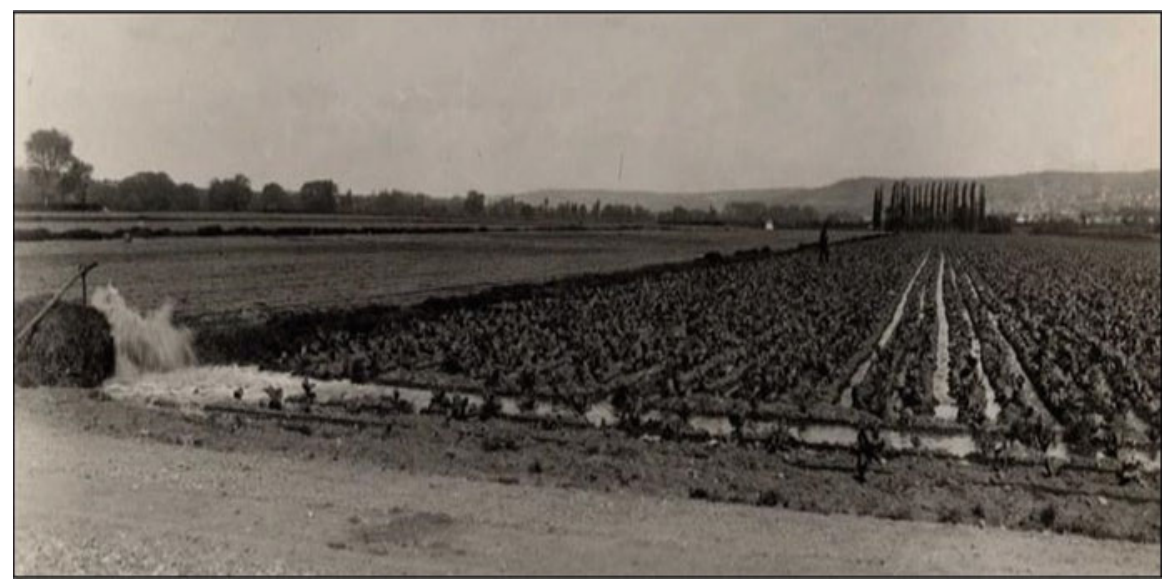

Fig. 6 Sewage farm (Credit: SIAAP)

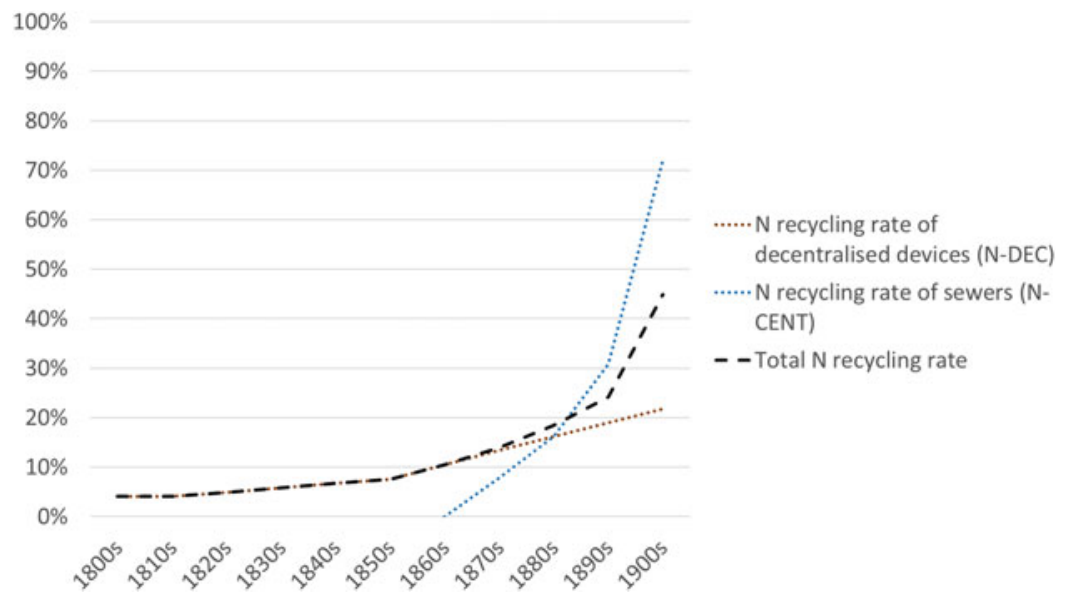

Fig. 7 Recycling rates of nitrogen in Paris: N-DEC (decentralised devices), N-CENT (sewer) and resulting total nitrogen recycling rate (1800s to 1900s) (see text for data sources)

in night soil collection and treatment techniques, N-DEC was multiplied by four, but it was still lower than $20 \%$ at the beginning of the twentieth century. In contrast, sewage farms were rapidly developed: 10 years after the tout-à-l'égout law, more than $70 \%$ of Paris's sewage water was actually spread on agricultural land, resulting in close to $50 \%$ total $\mathrm{N}$ recycling (Fig. 7).

Whereas the 1800-1868 period was marked by an intention towards circularity that failed to succeed in practice, the 1868-1905 period was characterised by a rapid shift in circularity mostly due to growing connection rates of toilets to sewers and adapted surfaces of sewage farms to be fertilised by human excreta. In 1888, Henri 
Baudrillart stated that "the entire population owes its well-being to this thorough metamorphosis" [32].

\section{Waste-Oriented Management Leading to Linearity (1905 to Today)}

\subsection{The Sacrifice of the Seine (1905-1968)}

The transformation of Paris human excreta management from unsuccessful to successful circularity took place in a few decades between 1890 and 1910 . However, several aspects explain that the circularity reached in the 1900 s would be the maximum value for the nineteenth and twentieth centuries.

Fossil deposits of $\mathrm{N}$ or $\mathrm{P}$ were discovered in the nineteenth century, and the chemical fertiliser industry grew. In 1913, the Haber-Bosch process made it possible to produce chemical $\mathrm{N}$ fertiliser from the $\mathrm{N}$ in the air $\left(\mathrm{N}_{2}\right)$. Urban fertilisers became less and less attractive to farmers [33]. Sewage spreading required large surfaces, and the benefits of agricultural production did not cover the costs of spreading: in the 1900 s, operational costs were more than ten times higher than the revenue of sewage farms [28].

In the $1900 \mathrm{~s}$, the population of Paris started to stabilise, in contrast to the population of the conurbation. The suburb sewage had to be managed, and sewage farms needed to be extended. When World War I began, most projects were interrupted: thereafter, sewage farms were not extended and their surface peaked in $1906 .{ }^{4}$ In the meantime, flush toilets had been adopted by the population. The campaign of house owners against sewers, which took place in the second half of the nineteenth century in Paris, was outstripped by the demand for flush toilets and sewers by households. After Paris, flush toilets began to spread to the suburbs (Fig. 8).

In 1905, authorisation was given by the Conseil Général de la Seine to test the intensive bacterial treatment of sewage. Human excreta and sewage were less and less considered as a resource and acquired the new status of waste. The Schéma général d'assainissement de la Seine, adopted in 1929, endorsed this point of view and promoted WWTPs as the way to achieve sanitation. Sanitary aspects dominated the relationship towards human excreta and Pierre Koch from the French Higher Council for Public Health ${ }^{5}$ stated in 1933 that "wastewater had to be destroyed" [4]. Wastewater irrigation decreased, but wastewater intensive treatment did not relay it. Circularity began to decline and pollution to rise. Whereas most pollution was widespread in the soil, underground water, rivers and air in the nineteenth

\footnotetext{
${ }^{4}$ New sewage farm extension projects were still studied after World War I, but they were not implemented.

${ }^{5}$ Conseil Supérieur de l'Hygiène Publique de France.
} 


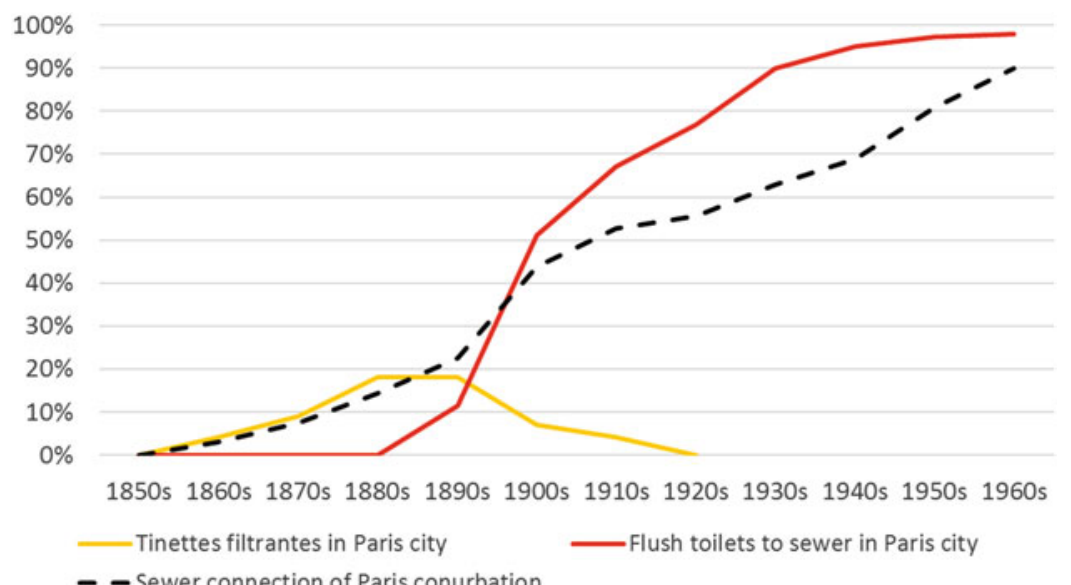

Fig. 8 Connection of toilets to the sewer system between the 1850s and the 1960s in the city of Paris and the Paris conurbation (see text for data sources)

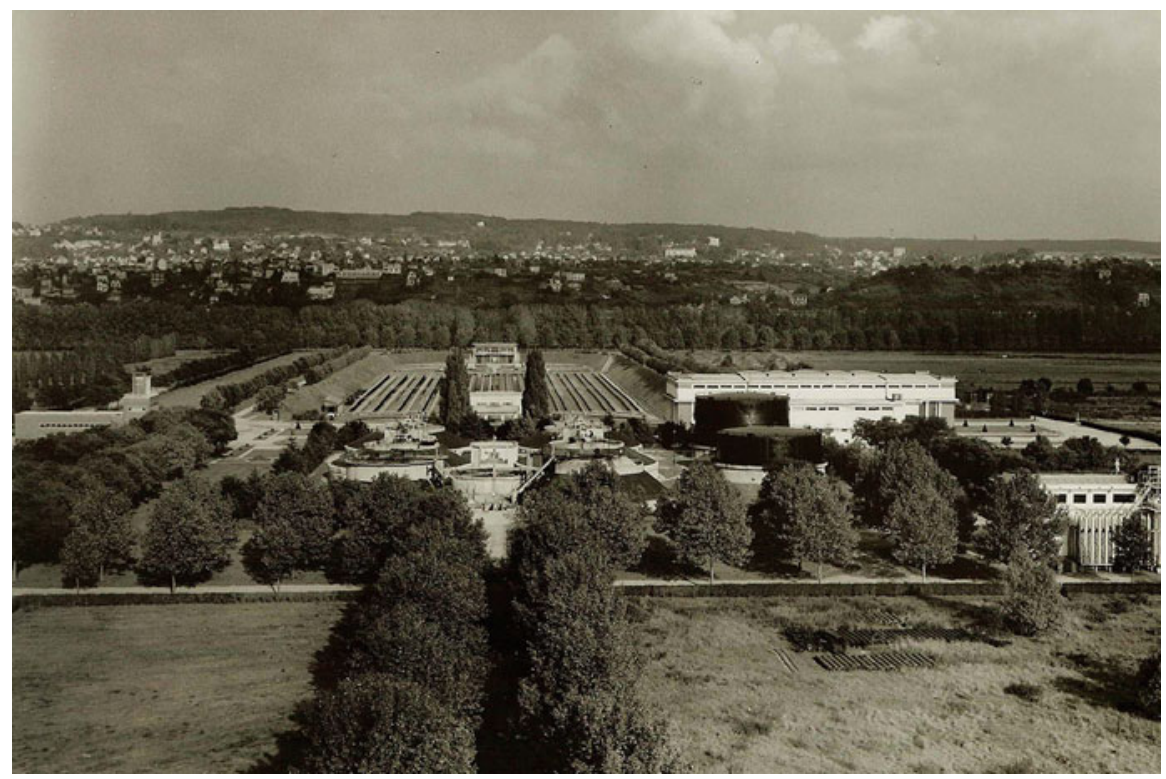

Fig. 9 Achères wastewater treatment plant in the 1960s (Credit: Barles collection)

century due to deficient dry collection, collection of human excreta in the sewers led to a pollution concentrated in the surface water. The first large WWTP, Achères, only started operation in 1940, and its size was largely insufficient for a population that exceeded five million inhabitants in the 1950s (Fig. 9). Less than $20 \%$ of human excreta was treated in this WWTP until the 1960s. Between the 1940s and the 1960s, 


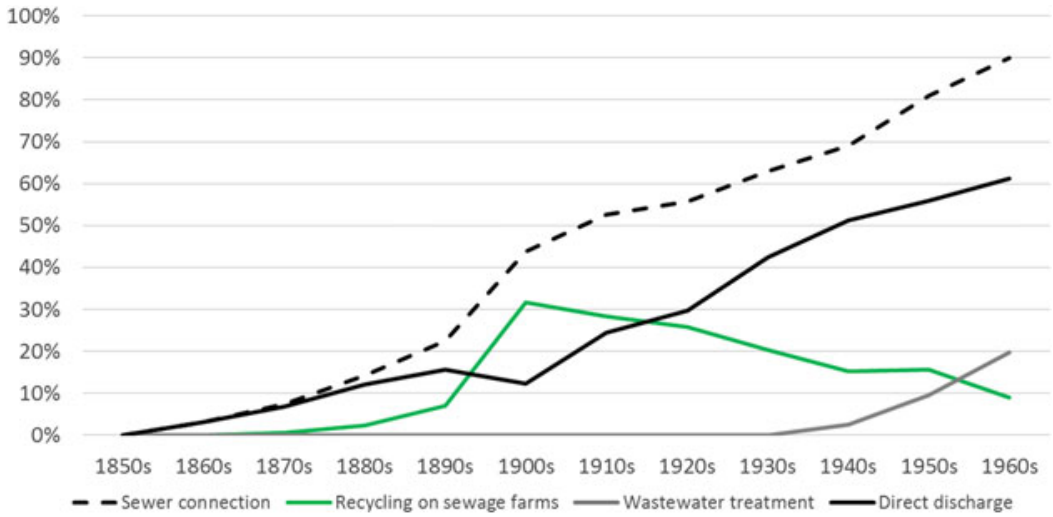

Fig. 10 Sewer connection of the Paris conurbation population and proportion of total human excreta recycled in sewage farms, directly discharged or treated in a wastewater treatment plant (1850s to 1960 s) (see text for data sources)

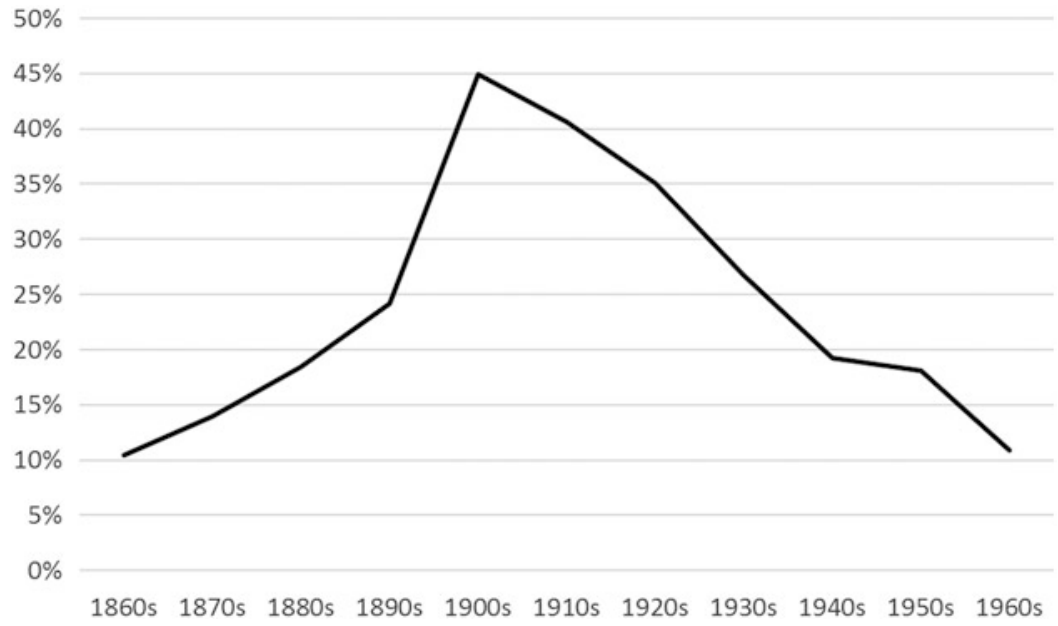

Fig. 11 Nitrogen recycling rate of the Paris conurbation (1860s to 1960s) (see text for data sources)

more than $50 \%$ of all human excreta of the Paris conurbation was directly discharged into the rivers via the sewers (Fig. 10).

This situation led to the "biological death" of the Seine, with less than $3 \mathrm{mg} \mathrm{O} \mathrm{L}^{-1}$, from Paris to the estuary, in summer at the end of the 1960s. Circularity had peaked above $40 \%$ in the 1900 s. In the $1960 \mathrm{~s}$, it was back to $10 \%$, the same level as in the 1860s (Fig. 11). 


\subsection{Pollution Treatment by Resource Destruction (1968 to Today)}

Concerns about the catastrophic quality of rivers grew after World War II, at a time when the Paris population was growing and the Seine was biologically dying. The 1960s were a turning point in the river's pollution: the national Water Law was enacted in 1964, urging recovery of surface water quality. In 1968, the Paris conurbation adopted a general wastewater management plan which aimed at treating all wastewater produced by the conurbation. It took several decades to achieve the main goal of this plan (Fig. 12).

At that time, wastewater treatment concentrated on reducing carbon (C) pollution. $\mathrm{N}$ and $\mathrm{P}$ removal in the first WWTP was quite low (less than $10 \%$ removal for $\mathrm{N}$ ). Between the 1970s and the 1990s, oxygen levels rose, but so did $\mathrm{N}$ and $\mathrm{P}$ pollution due to lack of sufficient treatment and an ever-growing population [13]. Even if sewage sludge was mostly spread on agricultural land, wastewater treatment reinforced the linearity of human excreta management because very little $\mathrm{N}$ and $\mathrm{P}$ were actually recovered in sludge. Sewage farms continued to disappear. Moreover, contamination of wastewater because of the mixing of human excreta with domestic water, industrial water and rainwater became a matter of concern. In the $2000 \mathrm{~s}$, high levels of contamination in metals were discovered in all sewage-covered farmlands and direct spreading of wastewater was forbidden.

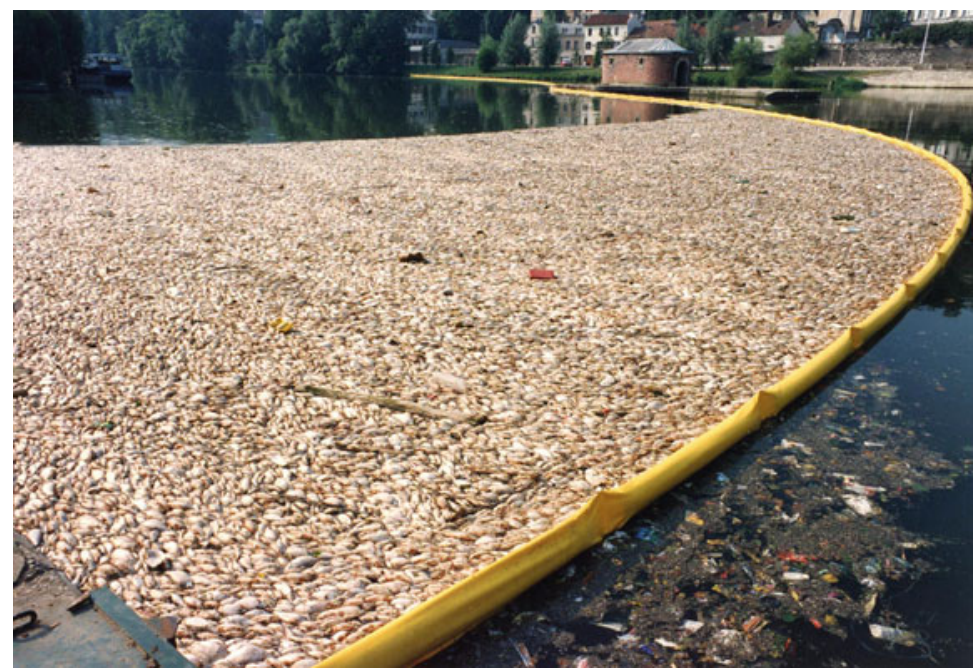

Fig. 12 The last large fish mortality event in the Paris conurbation due to wastewater discharge in the Seine. July 1994, Bougival (Credit: DRIEE-IF/Service Police de l'Eau) 
$\mathrm{N}$ and $\mathrm{P}$ pollution started to be addressed with the 1978 Paris Convention (becoming the OSPAR convention in 1992) and with the European Urban Waste Water Treatment Directive (UWWTD) in 1991. The transfer of N and P from Paris's excreta via the Seine and the English Channel to neighbouring countries led these countries in 1981 to request that the quantity of $\mathrm{N}$ and $\mathrm{P}$ released by the Seine River basin be divided by two between 1985 and 1995 (PARCOM recommendation 88/2). Similarly, the UWWTD required elimination of $70 \%$ of $\mathrm{N}$ and $80 \%$ of $\mathrm{P}$ from wastewater by 1998. In 2013, 25 years after the PARCOM recommendation and 15 years after the UWWTD deadline, just as France was about to be fined by the European Union for noncompliance, compatible $\mathrm{N}$ and $\mathrm{P}$ treatment were finally implemented in the Paris conurbation.

However, in this new human excreta management system, circularity is not the prevailing concern. Like $\mathrm{C}, \mathrm{N}$ is mainly lost by transfer to the atmosphere. Denitrification consists in the conversion of reactive nitrogen into the non-reactive form $\mathrm{N}_{2}$, the opposite of the Haber-Bosch process. On one hand, chemical $\mathrm{N}$ fertilisers are produced from $\mathrm{N}_{2}$ using fossil resources. On the other hand, human $\mathrm{N}$ contained in excreta is converted to $\mathrm{N}_{2}$ using fossil resources. The $\mathrm{N}$ imprint of Paris and the industrial world in general is thus considered unsustainable [14]. Today, one-third of the $\mathrm{N}$ of the Paris conurbation excreta is still discharged to the rivers, mainly in the form of nitrates. Two new forms of pollution also appear: nitrous oxide $\left(\mathrm{N}_{2} \mathrm{O}\right)$ gaseous emissions in the treatment process and nitrite $\left(\mathrm{NO}_{2}{ }^{-}\right)$discharged into the river. The global recycling rate of human $\mathrm{N}$ in Paris today is $5 \%$, the same value as with the inefficient dry management methods of the beginning of the nineteenth century.

The situation for $\mathrm{P}$ is ambiguous. Since it is possible to fix $\mathrm{P}$ in sludge via precipitation, $\mathrm{P}$ pollution treatment can simultaneously lead to increased $\mathrm{P}$ recycling. However, in Paris, incineration of sludge has been gradually implemented in the new WWTPs. P contained in ash is not recovered, and, in the 2010 s, a remarkable $84 \%$ treatment rate of $\mathrm{P}$ in WWTPs only leads to a $40 \%$ recycling rate, mostly because of sludge incineration [14] (Fig. 13).

\section{Future Human Excreta Management Scenarios}

\subsection{Lock-In and Opportunities}

Progressive adoption of the "toilet-sewer-wastewater treatment plant" combination since the end of the nineteenth century has created a sociotechnical lock-in in human excreta management. Modern comfort is associated with the disconnection of the population with their excreta and consumption of large volumes of water. With respect to human excreta management, the debate gradually shifted from the best possible management of human excreta itself to the management of mixed sewage water, then to the management of sludge and finally to the management of ash from incinerated sludge [7]. Nutrient pollution of the rivers has only been very recently 


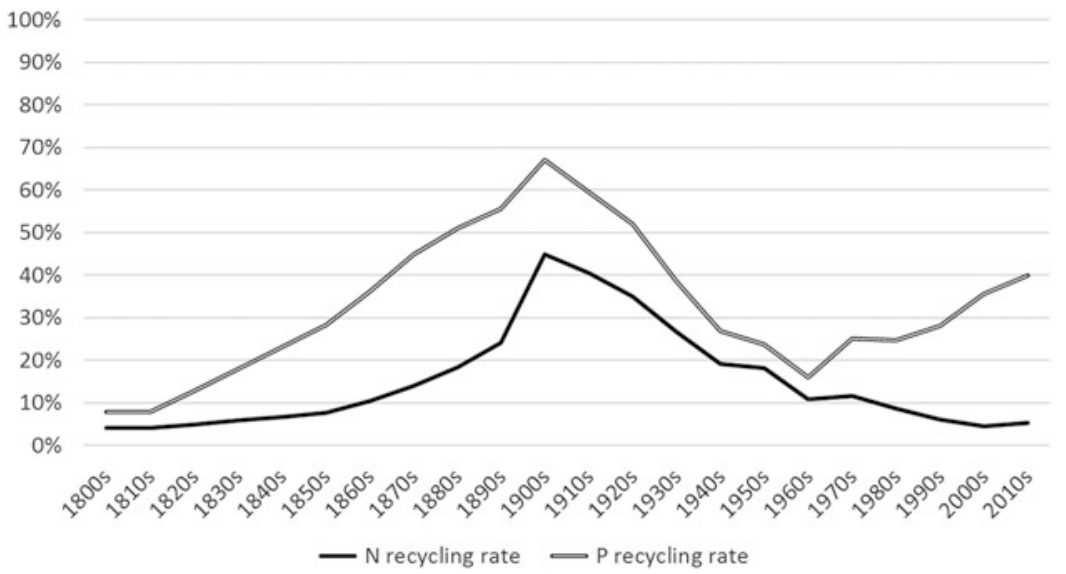

Fig. 13 Global N and P recycling rates of human excreta in the Paris conurbation (1800s to 2010s) (see text for data sources)

addressed, and the Seine's good status has still not been reached downstream of the Paris WWTPs. Circularity was only very recently conceptualised as a possible goal of human excreta management in the twenty-first century [7].

Considering the sociotechnical lock-in around "toilet-sewage-wastewater treatment plant", the less disruptive progression would be the transformation of WWTPs into recycling facilities. Since the concept of a circular economy has stepped up, the circular WWTP is very often put forward. However, it is subjected to many limitations. No technology is available today to implement large-scale $\mathrm{N}$ recovery from wastewater. The "circular wastewater treatment plant" is usually only circular on one element, $\mathrm{P}$, but not on $\mathrm{N}, \mathrm{C},{ }^{6} \mathrm{~K}$, etc. [7]. An unfavourable $\mathrm{C} / \mathrm{N}$ ratio in mixed sewage water (too much urinary $\mathrm{N}$ as compared to total wastewater $\mathrm{C}$ ) makes it very difficult to valorise both $\mathrm{C}$ and $\mathrm{N}$ in large-scale plants [34]. Today, the best technologies available do not allow for more than $\sim 30 \% \mathrm{~N}$ recycling. The 2018 IWA-NRR conference showed a new dynamic in $\mathrm{N}$ recovery research in WWTPs but without clear perspectives of the technologies that would be available in the future.

Since the 1990s, consciousness of the fertilising potential of human excreta, most particularly urine, has grown [35]. Many source separation initiatives have been implemented in buildings or ecovillages in Europe, starting in Sweden at the beginning of the 1990s and gradually spreading in Scandinavia and the Germanspeaking European countries [7]. The main concept is to (re-)divert urine, or urine and faecal matter, from the domestic sewage water and convert it into fertiliser. A review of these alternative human excreta management systems implemented in Europe shows that, until now, only urine source separation initiatives have managed to achieve circularity in human excreta management [7]. Source separation requires

\footnotetext{
${ }^{6}$ On a denitrifying WWTP, part of the carbon can be converted to valuable methane, but most of it is lost by oxidation as carbon dioxide.
} 

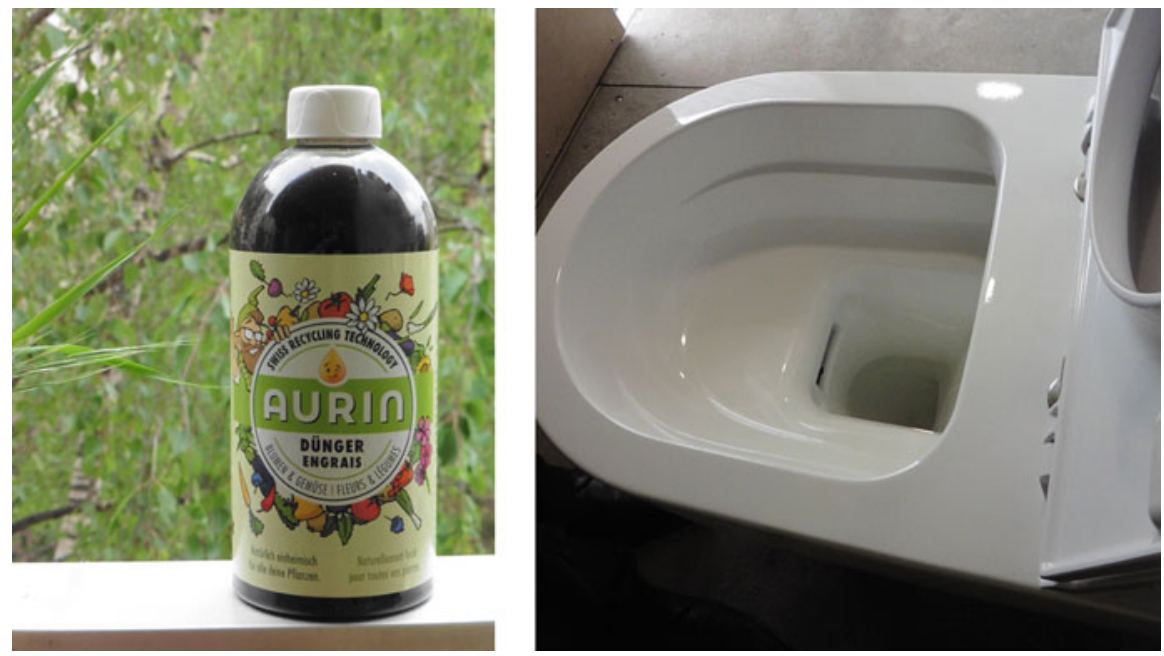

Fig. 14 Two new products related to circularity in human excreta management: urine-derived fertiliser Aurin (left) and urine-separating toilet Save! (right) (Credit: F. Esculier)

a profound change in the sociotechnical system associated with human excreta management. It still represents a niche innovation, but it is currently gaining attention in the Seine River basin. In October 2018, the Seine-Normandy Basin Committee $^{7}$ voted up to an $80 \%$ subsidy to source-separating projects.

A few models of urine-diverting flush toilets were developed in the 1990s and 2000s, and a new one has been marketed since March 2019 (Save! toilet by Laufen) (Fig. 14). Simultaneously, the first urine-derived fertiliser was officially licensed in 2018 by the Swiss Federal Office for Agriculture for use on all plants (Aurin by Vuna) (Fig. 14). Treatment and concentration of urine inside the toilet are also being developed [36]. This technology could allow changing an existing conventional toilet to a urine-diverting fertiliser-producing toilet without having to install new pipes in a building. Its deployment can thus potentially be faster than urine-diverting systems with pipe collection of urine. A socioecological transition of human excreta management towards circularity with deployment of decentralised and efficient dry management of excreta thus appears to be a plausible option.

\subsection{Recovering Circularity Through Source Separation}

Three scenarios have been developed for the future management of human excreta in the Paris conurbation for the $2020-2100$ period.

\footnotetext{
${ }^{7}$ In each large French water basin, the Basin Committee votes for fees and subsidies, associated with water uses and implemented by the Water Agencies.
} 
In scenario 1, called "Linearity", one can imagine that, due to difficulties in developing sewage sludge use because of micropollutant contamination and the complexity of its organisation, sewage sludge incineration increases from 50 to $100 \%$. $\mathrm{N}$ and $\mathrm{P}$ circularity decreases to $0 \%$, and human excreta management becomes totally linear. In this scenario, $\mathrm{N}$ and $\mathrm{P}$ pollution depends on the ability of the Paris conurbation to maintain its sewer network as well as intensive and efficient $\mathrm{N}$ and $\mathrm{P}$ treatment at the WWTP.

In scenario 2, called "End-of-pipe", one can imagine that circularity becomes a goal of human excreta management, but only end-of-pipe solutions are implemented. On one hand, with sludge $\mathrm{P}$ recycling, $\mathrm{P}$ soars to more than $80 \%$ circularity, exceeding the 1900 s recycling peak. On the other hand, $\mathrm{N}$ recycling remains limited to $30 \%$ circularity, below the 1900 s recycling peak.

In scenario 3, called "Circularity", a combination of source separation and end-ofpipe solutions is implemented. Urine diversion is compulsory in all new constructions (faecal matter can potentially be source-separated also, as long as it does not impair $\mathrm{N}$ and $\mathrm{P}$ circularity). In existing buildings, urine diversion is also implemented using toilet integrated treatment. In this scenario, we assume that the deployment speed of urine diversion in the Paris conurbation follows the same curve as flush toilet deployment in the city of Paris after the 1880s (Fig. 8). Urine diversion thus reaches $67 \%$ coverage in the 2040 s and $98 \%$ coverage in the 2090 s. Starting at $70 \%$ efficiency, the urine collection rate gradually increases up to $85 \%$ efficiency in the 2050s. End-of-pipe P recycling is implemented as in "End-of-pipe" scenario. Concerning $\mathrm{N}$, increasing urine diversion deeply modifies the $\mathrm{C} / \mathrm{N}$ ratio of sewage water. When complete separation of urine is achieved, $85 \%$ recovery of $\mathrm{N}$ at the sewage water treatment plants is assumed through $\mathrm{N}$ recovery from sludge with primary decantation and short retention time activated sludge [37]. We assume a linear progression of $\mathrm{N}$ recovery at the treatment plants.

With these hypotheses, $\mathrm{N}$ recycling already reaches $60 \%$ in the 2030 s, with $25 \%$ recycling at the sewage treatment plant and $35 \%$ in decentralised facilities. In the 2060s, N and P recycling exceeds $90 \%$, equally distributed between treatment plants and decentralised systems for $\mathrm{P}$, mainly through decentralised systems for $\mathrm{N}$. Consequently, $\mathrm{N}$ and $\mathrm{P}$ pollution is necessarily very low in all compartments of the environment. Figure 15 represents the $\mathrm{N}$ and $\mathrm{P}$ circularity of the Paris conurbation from 1800 to 2010 (historical data) with the addition of the 2020-2100 period with the circularity scenario. 


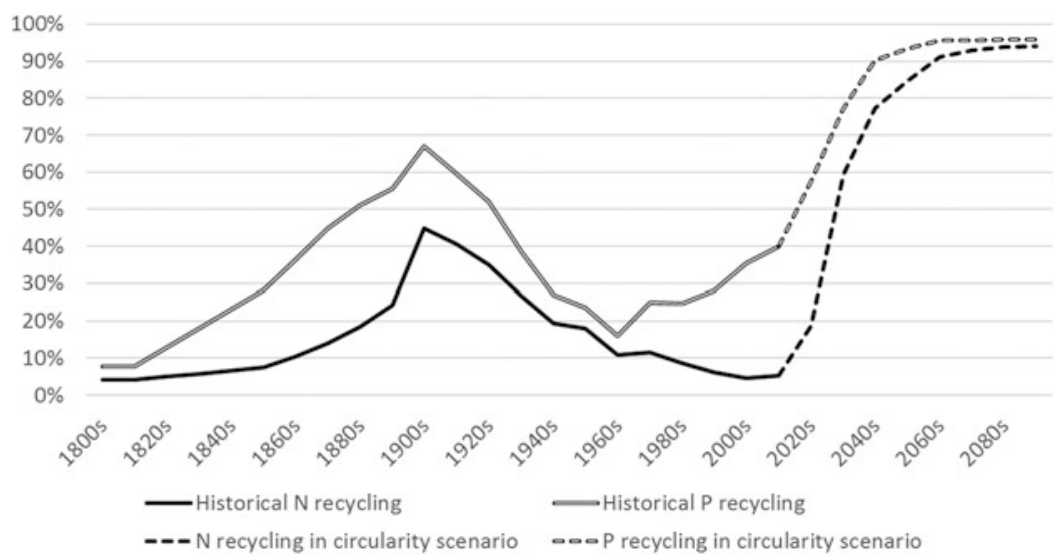

Fig. 15 Past $\mathrm{N}$ and $\mathrm{P}$ circularity of human excreta in the Paris conurbation and future $\mathrm{N}$ and $\mathrm{P}$ circularity in the "Circularity" scenario (see text for data sources)

\section{Conclusion}

Over the last two centuries, human excreta management has undergone great changes in Paris, some of them counterintuitive. Indeed, the driver of these transformations can be found in the goals that were assigned to this urban service: during the nineteenth century, it was as much dedicated to the improvement of public health as to the production of fertiliser, in order to prevent "hunger arising from the furrow, and disease from the stream" "[38]. Urban sanitation went hand in hand with rural food production; these two targets oriented technical choices towards the maximisation of nutrient recovery. Night soil was turned into poudrette, ammonium sulphate, urate and so on, moderately increasing recovery rates. The development of the domestic water supply during the second half of the nineteenth century raised a huge debate on the appropriateness of the combined sewer system associated with sewage farms. These were implemented during the last third of the century; sewer water spreading resulted in a huge increase in $\mathrm{N}$ and $\mathrm{P}$ recovery that rose to $50 \%$ at the beginning of the twentieth century. This moment can also be considered as the end of the circularisation phase.

The discovery of new sources of nutrients (fossil phosphates, potash mines as well as the Haber-Bosch process regarding N) disqualified urban fertilisers, and the recycling aim was abandoned. At the same time, the Paris urban area grew both in area and population, leading to an increasing production of human excreta and sewage. No longer of use, it was discharged into the river, which led to a severe pollution of the Seine River. The development of WWTPs since the 1940s was not sufficient to restore water quality, despite substantial amelioration since the 1980s (chapter "Ecological Functioning of the Seine River: From Long-Term Modelling Approaches to Highfrequency Data Analysis"). Simultaneously, the agricultural use of sewage sludge did not prevent decreasing $\mathrm{N}$ and $\mathrm{P}$ recycling rates, especially for $\mathrm{N}$

\footnotetext{
${ }^{8}$ La faim sortant du sillon et la maladie sortant du fleuve.
} 
(5\%): the metabolic linearisation was almost complete. On one hand, agriculture became specialised, disconnecting crop and livestock farming and leading to opened biogeochemical nutrient cycles (chapter "The Seine Watershed Water-Agro-Food System: Long-Term Trajectories of C, N, P Metabolism”); on the other hand, the final stage of agro-food nutrient management, i.e. urban human excreta management, reveals yet another disconnection, between food production and human excretion, with linear management of human excreta considered as waste.

This questions the future of urban sanitation systems and their aptitude to promote circularisation and achieve sustainability. A combination of source separation of urine (possibly with faecal matter) and end-of-pipe techniques gives the best results, with more than $90 \%$ recycling rates for both $\mathrm{N}$ and $\mathrm{P}$ around 2060 . This scenario is only feasible if human excreta are again considered as resources and if the aim of urban sanitation is redefined. This implies a complete transformation of the political basis of sanitation, a better integration of social metabolism in urban policies (and others), a decompartmentalisation of urban and rural policies. This also implies a change in sanitation techniques, the conception of buildings, the training of those who are in charge of these services and more generally of the material culture of urbanites. In short, a socioecological transition.

Acknowledgments The authors would like to thank all partners of the OCAPI programme (www. leesu.fr/ocapi) and the PIREN-Seine programme for their technical and financial support to this chapter. The PIREN-Seine research programme (www.piren-seine.fr) belongs to the Zone Atelier Seine part of the international Long-Term Socio-Ecological Research (LTSER) network.

\section{References}

1. Steffen W, Richardson K, Rockström J et al (2015) Planetary boundaries: guiding human development on a changing planet. Science 347(6223):1259855. https://doi.org/10.1126/sci ence. 1259855

2. Skambraks AK, Kjerstadius H, Meier M (2017) Source separation sewage systems as a trend in urban wastewater management: drivers for the implementation of pilot areas in Northern Europe. Sustain Cities Soc 28:287-296. https://doi.org/10.1016/j.scs.2016.09.013

3. Esculier F, Tabuchi JP, Créno B (2015) Nutrient and energy flows related to wastewater management in the Greater Paris: the potential of urine source separation under global change constraints. International conference on water, megacities and global change, Paris

4. Barles S (2005) L'invention des déchets urbains: France 1790-1970. Champ Vallon, Seyssel

5. Fischer-Kowalski M, Haberl H (2007) Socioecological transitions and global change: trajectories of social metabolism and land use. Edward Elgar, Cheltenham, Northampton

6. Barles S (2007) Feeding the city: food consumption and flow of nitrogen, Paris, 1801-1914. Sci Total Environ 375:48-58. https://doi.org/10.1016/j.scitotenv.2006.12.003

7. Esculier F (2018) Le système alimentation/excrétion des territoires urbains: régimes et transitions socio-écologiques. Thèse de doctorat en sciences et techniques de l'environnement. Université Paris-Est, Paris. https://hal.archives-ouvertes.fr/tel-01787854/document

8. Schmid Neset TS (2005) Environmental imprint of human food consumption: Linköping, Sweden 1870-2000. PhD thesis, Linköping studies in arts and science. Department of Water and Environmental Studies, Univ. Linköping 
9. Barles S (2002) L'invention des eaux usées: l'assainissement de Paris de la fin de l'ancien régime à la seconde guerre mondiale. In: Bernhardt $\mathrm{C}$, Massard-Guilbaud $\mathrm{G}$ (eds) Le Démon moderne. La pollution dans les sociétés urbaines et industrielles d'Europe/The Modern Demon. Pollution in Urban and Industrial European Societies. Coll. Histoires croisées, Presses de 1'Université Blaise Pascal, Clermont-Ferrand, pp 129-156

10. Préfecture de la Seine (1881-1959) Annuaires statistiques de la ville de Paris. Imprimerie Nationale, Paris

11. Jacquemet G (1979) Urbanisme parisien: la bataille du tout-à-l'égout à la fin du XIXe siècle. Rev Hist Mod Contemp 26(oct-déc):505-548

12. Bellanger E (2010) Assainir l'agglomération parisienne. Histoire d'une politique interdépartementale de l'assainissement (XIXe-XXe siècles). Avec la collaboration d'Éléonore Pineau. Éditions de L'Atelier, Paris

13. Rocher V, Azimi S (2017) Evolution de la qualité de la Seine en lien avec les progrès de l'assainissement de 1970 à 2015. Johanet, Paris

14. Esculier F, Le Noë J, Barles S et al (2018) The biogeochemical imprint of human metabolism in Paris megacity: a regionalized analysis of a water-agro-food system. J Hydrol 573:1028-1045. https://doi.org/10.1016/j.jhydrol.2018.02.043

15. Carré C, Mouchel JM, Servais P (2017) Assainir la banlieue de Paris: des fosses septiques au tout-à-l'égout, quels effets sur la qualité de l'eau de la Seine. In: Lestel L, Carré C (eds) Les rivières urbaines et leur pollution. Quae, Paris

16. Vincey P (1910) L'assainissement de la Seine et les champs d'épandage de la ville de Paris. Extrait des Mémoires de la Société nationale d'agriculture de France, t. CXLII, Paris

17. Bollon J, Filali A, Fayolle $\mathrm{Y}$ et al (2016) $\mathrm{N}_{2} \mathrm{O}$ emissions from full-scale nitrifying biofilters. Water Res 102:41-51. https://doi.org/10.1016/j.watres.2016.05.091

18. Bollon J, Filali A, Fayolle Y et al (2016) Full-scale post denitrifying biofilters: sinks of dissolved $\mathrm{N}_{2} \mathrm{O}$ ? Sci Total Environ 563-564:320-328. https://doi.org/10.1016/j.scitotenv.2016. 03.237

19. Le Noë J, Billen G, Esculier F et al (2018) Long term socio-ecological trajectories of agro-food systems revealed by $\mathrm{N}$ and $\mathrm{P}$ flows: the case of French regions from 1852 to 2014. Agric Ecosyst Environ 265:132-143. https://doi.org/10.1016/j.agee.2018.06.006

20. Boudriot PD (1986) Essai sur l'ordure en milieu urbain à l'époque pré-industrielle. Boues, immondices et gadoue à Paris au XVIIIe siècle. Histoire, économie société 5(4):515-528

21. Pluvinage $C$ (1912) Industrie et commerce des engrais et des anti-cryptogamiques et insecticides. J.-B. Baillière et fils, Paris. http://catalogue.bnf.fr/ark:/12148/cb31125773f

22. Pluvinage C (1927) Industrie et commerce des engrais - Engrais azotés et organiques, produits chimiques agricoles (tome 1). J.-B. Baillière et fils, Paris

23. Paulet M (1853) L'Engrais humain. Histoire des applications de ce produit à l'agriculture, aux arts industriels, avec description des plus anciens procédés de vidanges et des nouvelles réformes dans l'intérêt de l'hygiène. Comptoir des imprimeurs-unis, Veuve Comon, Paris

24. Boussingault JB (1858) Emploi des eaux de puits de Paris dans la panification. Gazette hebdomadaire de médecine et de chirurgie 5(29):507

25. Girardin J (1876) Des fumiers et autres engrais animaux, Septième édition. Garnier frères, Paris. http://catalogue.bnf.fr/ark:/12148/cb305108417

26. Héricart de Thury M (1820) Rapport à la société royale et centrale d'agriculture sur un nouvel engrais proposé sous le nom d'urate par MM. Donat et compagnie. Imprimerie de Madame Huzard, Paris

27. Beaudemoulin LA (1853) Assainissement de Paris. Revue de l'architecture et des travaux publics 11:131-138

28. Barles S (2007) Urban metabolism and river systems: an historical perspective - Paris and the Seine, 1790-1970. Hydrol Earth Syst Sci 11:1757-1769

29. Mille AA, Durand-Claye A (1869) Compte-rendu des essais d'utilisation et d'épuration. Régnier et Dourdet, Paris

30. Liger F (1875) Dictionnaire historique et pratique de la voierie, de la construction, de la police municipale et de la contiguïté: fosses d'aisances, latrines, urinoirs et vidanges. Baudry, Paris. https://gallica.bnf.fr/ark:/12148/bpt6k740549?rk=21459;2 
31. Arnould J (1889) Nouveaux éléments d'hygiène, 2nd edn. J. B. Baillière et fils, Paris

32. Baudrillart H (1888) Les populations agricoles de la France. Maine, Anjou, Touraine, Poitou, Flandre, Artois, Picardie, Île-de-France, passé et présent. Librairie Guillaumin, Paris, pp 455-626

33. Barles S, Lestel L (2007) The nitrogen question: urbanization, industrialization, and river quality in Paris, 1830-1939. J Urban Hist 33:794-812. https://doi.org/10.1177/0096144207301421

34. Larsen TA, Gujer W (1996) Separate management of anthropogenic nutrient solution (human urine). Wat Sci Tech 34(3-4):87-94

35. Drangert JO (1998) Urine blindness and the use of nutrients from human excreta in urban agriculture. GeoJ 45:201-208

36. Randall DG, Naidoo V (2018) Urine: the liquid gold of wastewater. J Environ Chem Eng 6:2627-2635. https://doi.org/10.1016/j.jece.2018.04.012

37. Wilsenach JA, van Loosdrecht CM (2006) Integration of processes to treat wastewater and source-separated urine. J Environ Eng 132(3):331-341. https://doi.org/10.1061/(ASCE)07339372(2006)132:3(331)

38. Hugo V (1862) Les Misérables, Lacroix, Verboekhoven et Cie. English translation: I. F. Hapgood, Thomas Y. Crowell \& Co, New York (1887)

Open Access This chapter is licensed under the terms of the Creative Commons Attribution 4.0 International License (http://creativecommons.org/licenses/by/4.0/), which permits use, sharing, adaptation, distribution and reproduction in any medium or format, as long as you give appropriate credit to the original author(s) and the source, provide a link to the Creative Commons licence and indicate if changes were made.

The images or other third party material in this chapter are included in the chapter's Creative Commons licence, unless indicated otherwise in a credit line to the material. If material is not included in the chapter's Creative Commons licence and your intended use is not permitted by statutory regulation or exceeds the permitted use, you will need to obtain permission directly from the copyright holder.

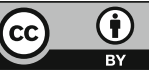

